\title{
5. Insights from the Great Depression
}

\section{Peter Temin ${ }^{1}$}

Unlike most of the lectures in the Insights series, I am not going to focus on the insights of any particular economist, but there are three people - two of them economists - from whom we can gain important insights right from the start.

John Maynard Keynes warned that '[p]ractical men, who believe themselves to be quite exempt from any intellectual influence, are usually the slaves of some defunct economist'. Karl Marx argued that '[h]istory repeats itself ... first as tragedy, then as farce'. Tip O'Neill, the second-longest serving Speaker of the House of Representatives (1977-87) said '[a]ll politics is local'.

With those thoughts in mind, let us examine today's trying economic times in light of the Great Depression and, more broadly, the period between the two world wars. I will structure things by examining the causes of the Great Depression, followed by the causes of the recent financial crisis, then I will repeat this pattern in discussing the spread of the crises and the recoveries. ${ }^{2}$

The Treaty of Versailles, which ended World 
War I, was the product of continuing hostility - a continuation of the war by nonviolent means. The allied victors wanted restitution and imposed guilt and reparations on Germany. The Germans were resistant, calling the treaty a 'stab in the back' - like Siegfried getting stabbed in Wagner's opera. Keynes opposed the treaty, writing The Economic Consequences of the Peace (1919), which was terrific polemic and makes good reading even today. It made his reputation but of course meant that he was not consulted by part of the government for quite a long time afterward. He predicted continuing conflicts from the Treaty.

We can see the economic failures of the interwar period as a tragedy in three acts, which we are in danger of repeating today. To understand Act I, we need to understand the gold standard. David Hume explained how a fixed exchange rate, like the gold standard, works. A small country that has a fall in exports does not have enough earnings to pay for its imports, so it pays in gold. When it loses gold there is less money circulating, so prices fall. But, when prices fall the exports from this country become cheaper in other countries, so its exports rise - and the country goes back to equilibrium. Hume's model, developed in the eighteenth century, assumed competitive markets and flexible prices - realistic assumptions for the 1700s, but not by the 1920s. The economy in Hume's time was agricultural, but by the 1920s economies were quite industrial - with 
large firms, unified labor forces, and much more stable prices and wages. Workers used to the war effort had a lot of solidarity in feeling that their wage levels should be preserved and they had gained considerable voting power.

Act I of the tragedy was that policymakers in places like Italy and Britain assumed Hume's model was right. These countries had inflation during the war, so they tried to reduce domestic prices to the prewar level to return to the gold standard after the war. This caused massive conflicts with workers. In Italy the political system was not strong enough to contain the conflict, and the Fascists took over with the March on Rome in 1922. In Britain democracy was older and stronger, but localized disruption grew into a general strike in 1926. France and Germany did not deflate, but they had a lot of internal conflicts too and when the Germans did not pay the reparations quickly enough the French invaded and occupied Germany's Ruhr region (1923-25).

This tension was somewhat contained by the middle of the 1920s at the beginning of Act II, a period I call the Apparent Calm. Both Germany and the US experienced economic booms. But then recessions began at the end of the decade. As countries entered this recession, they imported less, which meant other countries' exports fell. Hume's advice was followed and countries began deflating, but when many countries are deflating, they are chasing a moving target. This is because as each country deflates it imports less, 
which means other countries have their exports fall, so they deflate to try to get their exports to be cheaper. But when one country deflates, its trading partners' relative prices are higher, pushing them to deflate more so that their prices are cheaper and their exports can rise. Hume's deflationary mechanism works for a single small open economy, but not when everyone deflates simultaneously.

Now, let us switch to the modern period. The end of the Cold War brought about major new capital flows. The US changed from being a large lender to a large borrower. China grew and emerged as the largest lender. This triggered a housing boom in the US, and with the housing boom came structured finance. Mortgages were bundled together and divided into tranches. Those buying the top tranches had the first claim on the mortgage payments, making them safer, but those holding low tranches were last in line, making their payments much more risky. This was an innovation in finance designed to make finance more efficient. Instead of people holding individual mortgages, they could hold a tranche of mortgages to get the degree of risk that they desired. Individual mortgages can be risky - borrowers can move, die, lose their jobs, or get divorced. But once you had a tranche you had lots of parts of different mortgages, removing idiosyncratic risks like this. When housing prices went up all these tranches looked good. But, when housing prices went down they all looked bad. 
The first parallel is that the Great Depression and the Great Recession were both caused by nostalgia. Looking back on Hume's mechanism from the eighteenth century was an ideology that ignored economic changes. The Washington Consensus of the recent period was, similarly, an attempt to promote eighteenth-century conditions - minimal government, free competition in industry and finance, and stable exchange rates - in the US and in developing countries. Practical men relied on David Hume and Adam Smith. Atomistic competition was praised, markets were seen as efficient, so that regulations only reduced efficiency. But in the United States and Europe, large enterprises now exist. Oligopolies replaced competition. Governments are large parts of economies. And of course, wages are even less flexible now than they were earlier on. Second, people miscalculated as a result. They assumed risks were idiosyncratic - that the risks of deflation in the 1920s or the risks of not paying back a mortgage in the 2000s were independent risks. But, in fact, they turned out to be systemic risks. So excesses led to crises in both parts.

So that leads us then to Act III in Keynes's tragedy, the events of the early 1930s. Countries held on to the gold standard in the 1930s and deflated their economies - by keeping interest rates high and keeping spending low, which led to a series of currency crises in 1931. Germany's Chancellor Heinrich Brüning, speaking to a domestic audience, said that the government was 
thinking of not continuing to pay the reparations. He sent up a trial balloon, for domestic consumption, but doing so dried up international lending, and Germany had a currency crisis in June of 1931. When Britain announced a big government deficit, investors thought maybe the pound was going to follow the mark in leaving the gold standard, so they starting selling the pound and this run on the pound compelled Britain to abandon gold in September.

In the gold standard there were fixed exchange rates. To be on the gold standard a government allowed people to freely purchase or sell their currency for gold at a fixed price. When Germany had its crisis in June it kept the same rate, but controlled the purchases and sales. So the rate existed, but you could not actually buy and sell at that rate. In Britain they continued to buy and sell, but they would not maintain the rate, so the value of the pound went way down. Meanwhile the Bank of England kept its interest rate high, they said, to fight inflation - at a time when countries around the world were deflating. It took the British about six months to realize that if they were no longer retaining the price of the pound they did not need to keep the interest rate up, so they finally lowered the interest rate in an attempt to start an economic revival.

Germany had left the gold standard, so had Britain. Many worried that the United States would be next. The United States had an enormous amount of gold and the Federal Reserve 
raised the discount rate from 1.5 percent to 3.5 percent in October 1931 - right after Britain left the gold standard - in order to make it worthwhile for people to hold dollars, and save the gold standard. That is the point, I think, when the recession of the late 1920s turned into the Great Depression.

Today, the US has a flexible exchange rate, so it had a banking crisis instead of a currency crisis. The drop in housing prices made investors worry about all those tranches, thus precipitating the collapse and rescue of Bear Stearns in March 2008; the rescue of Fannie Mae and Freddie Mac, two quasi-government insurance companies, in August 2008; the bankruptcy of Lehman Brothers on September 15; and what amounted to the nationalization of AIG a couple days later. Lehman was allowed to go under, but not AIG. This confused markets, and they essentially froze as the price of risk soared. Everybody wanted to get rid of all these risky assets, but there were few buyers. Fire sales, quick sales at low prices, wrecked financial concerns' balance sheets. If your assets go way down in value because nobody will buy them then you have liabilities greater than your assets and are driven to bankruptcy.

Richard Koo (2008) in The Holy Grail of Macroeconomics: Lessons from Japan's Great Recession says there are two phases in the economy, yin and yang, shadow and light. The yin phase follows balance-sheet recessions. In the yin phase, when assets are less than liabilities in many companies, these companies will not be profit maximizers 
anymore. When they get money they add it to their assets, or they try to pay off some of their liabilities. But they will not invest; they will not act like profit maximizers, taking account of cheap money, so monetary policy stops working. So, fiscal policy is the only thing you can use in the yin economy, because monetary policy no longer works.

Koo argues that Keynes did not understand this. He analyzed a yin economy as if it were a yang economy. His followers emphasized yin policies after World War II but fiscal policies are not effective during yang phases, so they brought Keynesian thought into disrepute. Koo argues that there is a cycle. After a shadow phase, the economy recovers slowly, then when prosperity returns again people take more risks, then they take even more risks, and then they take so much risk that the economy crashes again before it slowly recovers. (Many of Koo's insights originated with Hyman Minsky.) These cycles occur over and over again - history repeats itself, as Marx warned.

Back to the interwar period. Franklin Roosevelt came into office in 1933 and introduced a new policy regime - a set of policies that are consistent, which convince people subject to these policies that broad policy has changed - rather than an isolated policy change, which does not shift people's expectations. There is a lot of discussion about whether Roosevelt's high wage policies prolonged unemployment in the Great Depression, 
but it is clear that economic growth returned. Then Roosevelt and the Fed both decided in 1936 that after 40 months of growth we must be out of the woods, so they reversed course and tightened up the economy so that inflation would not rise. Alas, it was too early, and they caused a very sharp recession in 1937.

Gauti Eggertsson (2008) uses a dynamic stochastic general equilibrium model to formalize an argument that Barry Wigmore and I made over 20 years ago (Temin and Wigmore, 1990). He models a closed economy, without financial intermediaries or monetary policy and concludes that Roosevelt's decisions to go off gold and to inflate prices to the pre-Depression level led to a recovery 'driven by a shift in expectations'.

This carried into the prosperity after World War II. Roosevelt's New Deal of the 1930s - policies like the Glass-Steagall Act (which separated commercial banking from investment banking), the establishment of the Securities Exchange Commission, and so forth - set up stability and prosperity. They gave prosperity in the decades after the war, from the 1950s into the 1970s, with a stable distribution of income, essentially no financial crises. But stability brought impatience with regulation. Then the Washington Consensus arose, income inequality rose, and the Glass-Steagall Act was repealed in 1999.

In 1997 East Asian crises occurred. Going back to Koo's argument, powerful elites in South Korea, Indonesia, and Singapore overreached and 
took big risks. They invested in ways that helped their countries but also enriched themselves. They acted as Koo and Minsky predicted, taking bigger and bigger risks and relying on their friends in government to bail them out if their gambles failed. They borrowed short to invest long, getting into a security mismatch.

A decade later, the Fed was slow to see another crisis coming. Once the crisis hit in September, 2008, the Fed bailed out the largest banks. Congress passed a stimulus bill, which was enough to keep us from having a depression, but not enough to restore prosperity. Republicans say the glass is half empty, that is we are not at full employment. Democrats say the glass is half full, we did not have a depression. In 2010 Congress passed the DoddFrank bill, which was rather ambitious. One part of it aimed to reinstate an essential feature of the Glass-Steagall Act - this is the Volcker Rule - but in the regulations to enforce the bill the distinction has been blunted a great deal.

Why didn't we have the Great Depression II? Partly because of the vagaries of the US election cycle. We only have presidential elections every four years. It came three years after the initial crisis in the 1930s. It came three months after the crisis in 2008 - as I said the new president passed the stimulus bill. But while he had the opportunity to make more fundamental changes, he did not have the political mandate to. He did not have the overwhelming majority in Congress 
that Roosevelt had after three years of depression.

Now we are worried about events in Europe and a return to recession, so let me turn to the current events. But before we do, just think about Marx again. We are not yet in a world depression, we do not have people out on the streets selling apples - we now have safety nets - so history is repeating itself as farce rather than tragedy.

The Great Depression unfolded over time - first a downturn in 1929, then currency crises in 1931. In the recent case the financial crisis started in 2008, with the euro crash in 2012. The experiences of the interwar period showed us the problems of the gold standard and fixed exchange rates, but in recent years we have rebuilt a system similar to it. We have a world with currency areas that have flexible rates relative to each other, but fixed exchange rates within the currency areas. The euro is the currency in Europe, and the United States has a fixed exchange rate with China. These came about in entirely separate ways. The Euro Zone was established by a treaty, and it is noteworthy that the treaty did not have an escape clause. In the gold standard it was each country's decision whether they wanted to stay on or off gold - Germany and Britain could go off gold in 1931, but the United States decided to stay on it. But they did not put an escape hatch in the treaty for the euro - because they feared it might encourage speculation. Of course, now there has 
been no end to speculation about whether Greece or Spain or Italy is going to default or leave the euro. The euro is a very fixed system. Meanwhile, the renminbi rate is set by China pegging its rate to the dollar, so there is nothing the US can do to get out of it. In a sense it is like staying in the euro system. The US government talks to the Chinese about this all the time but nothing happens to allow the US dollar to depreciate against the renminbi.

Germany today is like the US was in the 1920s, running large surpluses. These German surpluses affect Southern Europe. Figure 5.1 shows that since the euro was created in 2000, Germany has run large current account surpluses and the

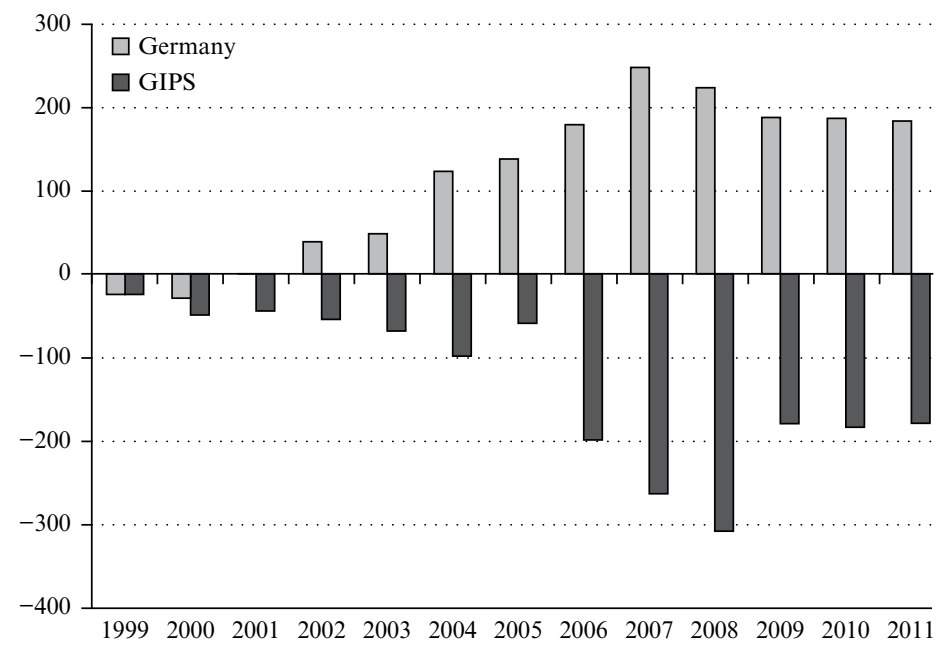

Figure 5.1 Current account balances (\$ billion), Germany versus GIPS (Greece, Italy, Portugal, Spain) 
Southern European countries (GIPS - Greece, Italy, Portugal, Spain) have run large deficits.

Booms in Southern Europe in the last decade caused wages to rise and imports to surge, but now they need to get back into balance. They need wages to fall because they cannot devalue their currencies. They cannot go off the euro as countries could go off gold earlier, because there is no escape clause. So instead of changing the price of foreign exchange, they have to change the price of labor. But since they are no longer agricultural economies, reducing wages is very hard to accomplish. So they have adopted austerity plans, which are effectively the same as the deflationary plans of the 1930s.

German Chancellor Angela Merkel has represented this as the Germans being virtuous - they are living within their means, exporting, being productive - but Southern Europeans, particularly the Greeks, are dishonest and disreputable. She has characterized the problem as virtuous versus less virtuous people, and has promoted austerity everywhere. But the problem with austerity is that it prevents countries from paying their debts. Deflating makes debts harder to pay, because austerity causes their economies to contract. Everyone is looking at the ratio of debt to their gross domestic product, but this ratio rises when incomes go down. Germany needs to do something different. But here is Tip O'Neill's theme - all politics is local. Chancellor Merkel speaks to her domestic supporters, and 
advocates austerity, advocates what she thinks of as being respectable people, and does not support devaluation, does not support countries leaving the euro. She is just like Brüning in 1931, whose idea of not paying any more reparations was designed for a domestic audience, but was heard by the rest of the world. She has generated a currency crisis.

With China and the US, it is the same kind of situation that we see with Germany and Southern Europe. China has large surpluses like Germany, which imposes a burden on other countries. So think of the US as being Spain, and we cannot devalue. In order for us to recover again, China, like Germany, would have to change its policies to reorient demand. China is not changing the nominal exchange rate, but the boom in China has led to higher wages, so the real exchange rate - not the price of the currency, but the price of goods in the foreign currency relative to prices of goods in domestic currency - is rising, even though the nominal exchange rates are pegged. That may help a little bit.

Both Germany and China are surplus countries with fixed exchange rates. It is worse than the gold standard, because there is no escape clause. The countries in Southern Europe and the US face limited options. Greece cannot devalue, because it is in the euro system. The US cannot devalue relative to the renminbi. So what should be done? We could adopt a Keynesian system. Keynes wanted to recognize that there are two sides to the figure 
above - it is not just the deficit countries that need to change, but also the surplus countries.

A lot of these struggling countries also have large government deficits. They did not want to have a financial crisis similar to the 1930s, so their governments injected capital into the banks. They got the capital by issuing government bonds. These governments have provided a lot of the capital for banks, so they should be treated like stockholders, get information, returns, and have some effect on the policies.

What are the ultimate lessons?

Lesson one: The world economy is prone to collapse. Recovery measures work, but memories fade, and then the cycle begins again. So anybody who tells you we can do something so we'll never have another economic crisis is either lying or foolish. There are reforms that can postpone or slow down the transit around this circle; but not eliminate it.

Lesson two: Only a Great Depression produces genuine reform. Keynes was right, that practical men rely on dead economists. Marx was right that history repeats itself, and Tip O'Neill was right too.

\section{Notes}

1. This talk was given at Wake Forest University on March 1, 2012.

2. My analysis uses the approach of a Keynesian openeconomy macroeconomic model. I do not find dynamic stochastic general equilibrium (DGSE) models helpful. See my review essay (Temin, 2008). 


\section{References}

Eggertsson, G. (2008), 'Great Expectations and the End of the Great Depression', American Economic Review, 98, 1476-1516.

Keynes, J.M. (1919), The Economic Consequences of the Peace, London: Macmillan.

Koo, R. (2008), The Holy Grail of Macroeconomics: Lessons from Japan's Great Recession, Hoboken: John Wiley \& Sons.

Temin, P. (2008), 'Real Business Cycle Views of the Great Depression and Recent Events: A Review of Timothy J. Kehoe and Edward C. Prescott's "Great Depressions of the Twentieth Century"', Journal of Economic Literature, 46 (3), 669-684.

Temin, P. and B. Wigmore (1990), 'The End of One Big Deflation', Explorations in Economic History, 27, 483-502. 